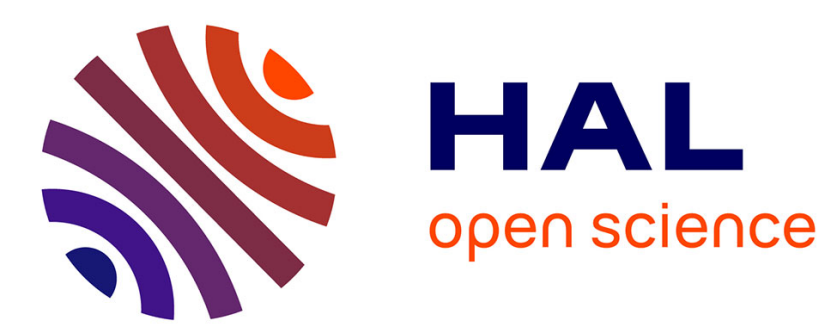

\title{
Generation of Fertile Cloned Rats by Regulating Oocyte Activation
}

Q. Q. Zhou, Jean-Paul Renard, Gaelle Le Friec, Vincent V. Brochard, Nathalie Beaujean, Yacine Cherifi, Alexandre Fraichard, Jean Cozzi

\section{> To cite this version:}

Q. Q. Zhou, Jean-Paul Renard, Gaelle Le Friec, Vincent V. Brochard, Nathalie Beaujean, et al.. Generation of Fertile Cloned Rats by Regulating Oocyte Activation. Science, 2003, 302 (5648), pp.1179-1179. 10.1126/science.1088313 . hal-02610656

\section{HAL Id: hal-02610656 https://hal.science/hal-02610656}

Submitted on 17 May 2020

HAL is a multi-disciplinary open access archive for the deposit and dissemination of scientific research documents, whether they are published or not. The documents may come from teaching and research institutions in France or abroad, or from public or private research centers.
L'archive ouverte pluridisciplinaire HAL, est destinée au dépôt et à la diffusion de documents scientifiques de niveau recherche, publiés ou non, émanant des établissements d'enseignement et de recherche français ou étrangers, des laboratoires publics ou privés. 


\section{Brevia}

\section{Generation of Fertile Cloned Rats by Regulating Oocyte Activation}

Qi Zhou, ${ }^{1,2}$ Jean-Paul Renard, ${ }^{1} *$ Gaëlle Le Friec, ${ }^{3}$ Vincent Brochard, ${ }^{1}$ Nathalie Beaujean, ${ }^{1}$ Yacine Cherifi, ${ }^{3}$ Alexandre Fraichard, ${ }^{3}$ Jean Cozzi ${ }^{3}$

${ }^{1}$ Developmental Biology and Reproduction Unit, INRA, Jouy en Josas, France. ${ }^{2}$ Institute of Zoology, CAS, Beijing, RP of China. ${ }^{3}$ genOway, Lyon, France.

*To whom correspondence should be addressed. E-mail: renard@jouy.inra.fr

The rat is a reference animal model for physiological studies and for the analysis of multigenic human diseases such as hypertension, diabetes and neurological disorders (1). Genetic manipulation in the rat is hampered by the lack of suitable technologies such as embryonic stem cells (ES) which are routinely used to generate targeted mutations in the mouse. Cloning through somatic cell nuclear transfer (SCNT) is a potential alternative approach in species for which ES technologies are unavailable. However, all previous efforts to clone rats have been unsuccessful, with developmental arrest at implantation stage ( 2 and references therein).

The fine-tuned coordination between nuclear transfer and timing of oocyte activation is critical to the outcome of somatic cloning. This coordination is hampered in the rat because almost all the oocytes spontaneously, although abortively, activate within $60 \mathrm{~min}$ of their removal from oviducts (3). Such rapid but incomplete activation process is not encountered in other cloned species. To allow embryo reconstruction before the onset of oocyte activation, we initially developed a one-step SCNT procedure for the rapid substitution of the endogenous meiotic metaphase by an exogenous mitotic one. This latter was isolated from synchronized cultured fetal CD-SpragueDawley fibroblasts (12.5 dpc). Individual mitotic nuclei were injected into a recipient OFA-SpragueDawley oocyte, from which the meiotic metaphase was withdrawn while removing the micropipette from cytoplasm after injection. However, within 30 min after recovery $70 \%$ of oocytes showed clear morphological evidence of spontaneous release from MII (Fig. 1A). When activation of cloned embryos (Fig. 1B) was induced and maintained by exposure to a cdc2-specific kinase inhibitor (Butyrolactone; $150 \mu \mathrm{M}, 2 \mathrm{~h}$ ) (4), 201 out of 221 reconstructed embryos expelled the polar body and subsequently divided into two-cell embryos. Their transfer into OFA-SpragueDawley foster mothers (11 recipients, 221 embryos) resulted in 9 implantation sites, but no fetal development.

Forty percent of oocytes selected for SCNT turned to be already activated as evidenced by disjoined sister chromatids moving to opposite poles (Fig. 1C). These observations strongly supported the view that despite rapid manipulation, most of the oocytes were not suitable for cloning. As activation is triggered by the inactivation of MPF activity through a proteasome-mediated cyclin degradation pathway, we used MG132, a protease inhibitor that reversibly blocks the first meiotic metaphase-anaphase transition in the rat (5). We found that this drug also reversibly stabilized most oocyte MII metaphases for up to 3 hours (77\%; Fig. 1D).

We then collected oocytes in the presence of MG132 $(5 \mu \mathrm{M})(4)$ as described above. SCNT was performed within 30 minutes of drug removal. 876 embryos were implanted into 12 pseudopregnant foster female rats. At $12.5 \mathrm{dpc}$, the females were sacrificed, and four females contained 16 fetuses. Thirteen of the fetuses, obtained from 3 females, were viable with beating hearts (Fig 1E). In the next series of experiments, we transplanted 129 cloned embryos into two foster mothers and allowed them to go to term. Only one foster mother contained viable fetuses and this animal delivered three live male pups of fibroblast origin as unambiguously demonstrated by microsatellite marker analysis (4). One normal sized pup (5.9 g) died a few hours after birth. The other two pups grew to sexual maturity (Fig. $1 \mathrm{~F})$ and generated normal progeny.

We have also obtained normal progenies (size, weight and development) from two additional cloned female rats demonstrating the potential of the technique for the development of fertile rat lines of both sexes (supporting online text).

Our data highlight the importance of adapting the SCNT procedure to oocyte physiology for successful cloning. Recently, random mutagenesis has been proposed to generate knock-out rats (6). Our results however pave the way for more extensive genetic modifications such as conditional knock-out and gene replacement which are required to produce relevant models of human diseases.

\section{References and Notes}

1. H.J. Jabob and A. Kwitek, Nature Rev. Genet. 3, 33 (2002).

2. M. Hirabayashi et al., Cloning Stem Cell. 5, 35 (2003).

3. M. Zernicka-Goetz, Mol. Reprod. Dev. 28, 169 (1991).

4. Materials and Methods are available as supporting material on Science Online.

5. L.B. Josefsberg et al., Biol. Reprod. 62, 1270 (2000).

6. Y. Zan et al., Nature Biotechnol. 21, 645 (2003).

7. Funding is provided by Institut National de la Recherche Agronomique (INRA) and genOway Company. We thank P. Hardy (DVM, Charles River Laboratories, France) and C. Szpirer (ULB) for their contribution to rat genotype analysis. We also acknowledge P. Adenot for INRA confocal facility and B. Nicolas for technical help during the preparation of this manuscript.

Supporting Online Material

wwW.sciencemag.org/cgi/content/full/1088313/DC1

Materials and Methods

SOM Text

Fig. S1

Tables S1 to S3

References

23 June 2003; accepted 22 September 2003 
Published online 25 September 2003;

$10.1126 /$ science. 1088313

Include this information when citing this paper.

Fig.1. (A) A freshly recovered rat oocyte with a marked cytoplasmic protrusion (arrowhead) revealing an ongoing activation process. (B) A rat oocyte used for micromanipulation. (C) DNA status of oocytes after recovery in standard conditions reveals the presence of two separate sets of chromatids whereas after recovery in MG132 supplemented medium (D) reveals a stabilized metaphase plate. Normal cloned fetus (E) at day $14.5 \mathrm{dpc}$ and two adult cloned male rats $(\mathbf{F})$ obtained using MG132 supplemented medium. Scale bar $10 \mu \mathrm{m}$ (A) to (D) and $1 \mathrm{~mm}$ (E). 


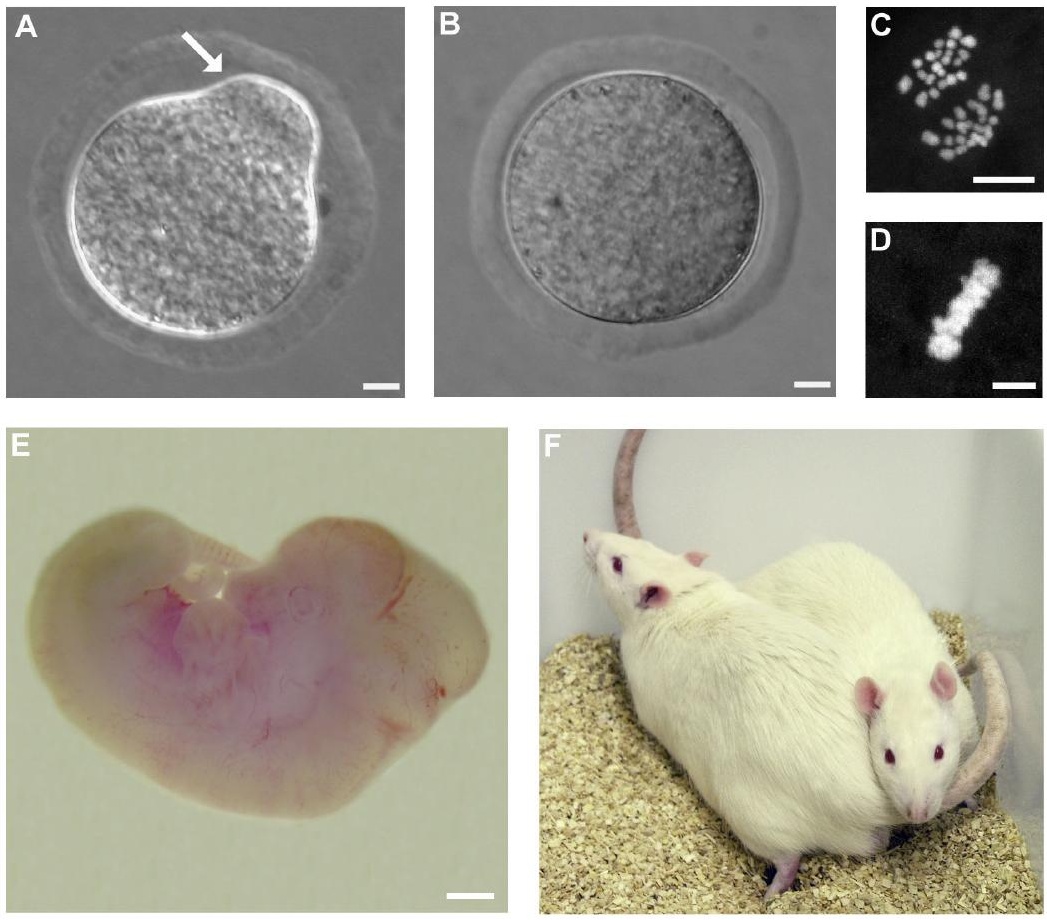

